\title{
Risk Assessment of Total and Faecal Coliform Bacteria From Drinking Water Supply of Badin City, Pakistan
}

\author{
Aziz Ahmed $^{1 *}$, Tarique Mahmood Noonari', \\ Habibullah Magsi ${ }^{3}$, Amanullah Mahar ${ }^{4}$ \\ ${ }^{1 *}$ Aalborg University, Department of Development \& Planning \\ Aalborg East, Denmark \\ ${ }^{2}$ Pakistan Council of Research in Water Resources, Water Quality Laboratory \\ Badin, Sindh, Pakistan \\ ${ }^{3}$ UMR SAD-APT, INRA AgroParisTech, Paris Cedex 05 \\ France, \& Sindh Agriculture University, Tando Jam \\ ${ }^{4}$ Centre for Environmental Sciences, University of Sindh \\ Jamshoro, 76080, Pakistan
}

*Corresponding author:Tel ++45 71986 696; Email: aahme12@student.aau.dk

\begin{abstract}
The present research work carried out to examine drinking water quality in Badin city of Sindh province, Pakistan. Water samples were collected from eighteen different sites representing main source, distribution system and end-user throughout the city. The aim of this study was to determine presence of total and faecal coliform bacteria in drinking water being supplied to the citizens and sensitize concerned authorities for remedial measures. Potalab (WAG-WE 10010, Water Testing-Advanced Long-Term Monitoring Kit) was used for water quality monitoring. Results obtained, revealed that $\mathrm{pH}, \mathrm{EC}(\mu \mathrm{S} / \mathrm{cm})$ and $T D S(\mathrm{mg} / \mathrm{l})$ were within permissible limits, whereas turbidity, residual chlorine, total and faecal coliforms were not in compliance with WHO standards. Presence of total and faecal coliform bacteria was found in all the water samples which indicated severity of contamination in the drinking water for human health. However, no residual chlorine was detected in any of the water samples underpinning dysfunctional treatment system.
\end{abstract}

KEYWORDS: Water quality, Total Coliform, Faecal coliform, Contamination

\section{Introduction}

The quality of drinking water is a main environmental constraint in the field of health. Access to safe drinking water is the basic human right of every citizen and ensuring provision of safe drinking water is of paramount importance to protect health of the communities, however access to this basic need is a big challenge for Pakistan in the present century. Assurance of drinking-water safety is a foundation for the prevention and control of waterborne diseases. Research studies globally 
(WHO and UNICEF, 2008) have reported that, eight hundred eighty four million individuals lacking improved drinking water source (i.e., safe source from faecal contamination), and 2.5 billion individuals do not have access to better sanitation (i.e., a safe disposal of human excreta).

Annually, about 1.5 million children under the age of five die of diarrhoea linked to inadequate water, sanitation and hygiene facilities. In developing world, diarrhoea is a main waterborne infection which is significantly responsible among other reasons for death and disease burden in children (UNICEF/WHO 2009; Kosek et al., 2003; Prüss et al., 2002). It is reported that that diarrhoea is the second foremost reason of morbidity in Pakistan i.e. 22 percent and the primary cause of mortality for children under five (Government of Pakistan, 2008). State Figures report 56 percent of the total population has access to safe drinking water (Farooq et al., 2008).

However, only 25.6 percent (rural 23.5 percent and 30 percent urban) of the population in Pakistan has access to this basic amenity as per international standards for safe and potable water (Rosemann, 2005). Drinking water being delivered by municipalities to the public is mostly contaminated with infectious microorganisms or hazardous chemicals (WWF, 2007).

The Government of Pakistan is taking measures to provide sufficient quantity of safe drinking water at an affordable cost and in an equitable, efficient and sustainable manner (Government of Pakistan, 2009). However, Pakistan Council of Research in Water Resources (PCRWR) carried out a detailed water quality monitoring from 2002 to 2006 in twenty three major cities of four provinces of the country. The result of the study revealed that an average of 84-89percent of water sources all over the country have below recommended level of water quality for human consumption (PCRWR, 2007).

Bacteriological contamination has been considered major drinking water problem in Pakistan (PCRWR, 2004). Bacterial contamination of surface and groundwater is usually due to mixing of surface runoff passing through urban areas and pastures, leakage of sewage disposal systems and septic tanks, overloaded sewage treatment plants, disposal systems and raw sewage deep well injection (PCRWR, 2004). Moreover, cross-connection, wrecked or leaking pipes, back siphonage (backflow of polluted or contaminated water, from a plumbing fixture or cross-connection into a water supply line, due to a lowering of the pressure in the line) and irregular water supply result in contamination of the distribution system (PCRWR, 2004; Shar et al., 2008b).

Earlier studies conducted for Khairpur district of Sindh witnessed the presence of total and faecal coliforms in all 90 (100 per-cent) water samples collected from the main source, distribution networks and end users (Shar et al., 2008a). The situation is almost same in other main cities of the country like Peshawar, Lahore and Karachi. Drinking water was found bacteriologically contaminated in all these cities 
(Anwar et al., 1999, 2004; Hussain et al., 2007; Mumtaz et al., 2010; Sarwar et al., 2004; Zahoorullah et al., 2003)

This paper analyses drinking water quality at eighteen different locations in Badin city including main reservoir, distribution lines and household consumers. The main objectives of the present research study was to present substandard status quo of drinking water quality in district Badin, southern Pakistan to sensitize the concerned authorities such as district government, Taluka/Tehsil Municipal Administrations (TMAs) and Public Health Engineering Department (PHED) and to recommend appropriate measures for water quality improvement to protect health of the communities. The research explores level of bacteriological contamination and their reasons in drinking water of Badin city.

\section{Sampling Locations}

Table 1: Sampling locations

\begin{tabular}{|c|c|c|c|c|c|c|c|c|c|}
\hline $\begin{array}{c}\text { Sample } \\
n^{0}\end{array}$ & 1 & 2 & 3 & 4 & 5 & 6 & 7 & 8 & 9 \\
\hline $\begin{array}{c}\text { Sample } \\
\text { Site }\end{array}$ & $\begin{array}{l}\text { WSS } \\
\text { Phase- } \\
\text { II } \\
\text { (pond) }\end{array}$ & $\begin{array}{l}\text { WSS Phase- } \\
\text { II } \\
\text { distribution } \\
\text { pipe }\end{array}$ & $\begin{array}{l}\text {-Sahekar } \\
\text { Foundation }\end{array}$ & $\begin{array}{l}\text { Shah } \\
\text { n Latif } \\
\text { Imam } \\
\text { Bargah }\end{array}$ & $\begin{array}{l}\text { Govt } \\
\text { Islamia } \\
\text { Degree } \\
\text { College }\end{array}$ & $\begin{array}{l}\text { Railway } \\
\text { Sahahbaz } \\
\text { colony }\end{array}$ & $\begin{array}{l}\text { Noor } \\
\text { Mustafa } \\
\text { Mosque } \\
\text { sirani } \\
\text { road }\end{array}$ & $\begin{array}{l}\text { Revenue } \\
\text { colony }\end{array}$ & $\begin{array}{l}\text { Ansari } \\
\text { Mohalla }\end{array}$ \\
\hline $\begin{array}{c}\text { Sample } \\
n^{0}\end{array}$ & 10 & 11 & 12 & 13 & 14 & 15 & 16 & 17 & 18 \\
\hline $\begin{array}{l}\text { Sample } \\
\text { Site }\end{array}$ & $\begin{array}{c}\text { WSS } \\
\text { Phase- } \\
\text { III } \\
\text { (pond) }\end{array}$ & $\begin{array}{l}\text { WSS Phase } \\
\text {-III } \\
\text { distribution } \\
\text { pipe }\end{array}$ & $\begin{array}{l}\text { Police line } \\
\text { HQ }\end{array}$ & $\begin{array}{c}\text { Govt } \\
\text { Boys } \\
\text { High } \\
\text { School }\end{array}$ & $\begin{array}{l}\text { Highway } \\
\text { Department } \\
\text { mosque }\end{array}$ & $\begin{array}{c}\text { Mehran } \\
\text { t Hotel }\end{array}$ & $\begin{array}{c}\text { Civil } \\
\text { Hospital }\end{array}$ & $\begin{array}{l}\text { Agrovil } \\
\text { colony }\end{array}$ & $\begin{array}{c}\text { Irrigation } \\
\text { colony }\end{array}$ \\
\hline
\end{tabular}

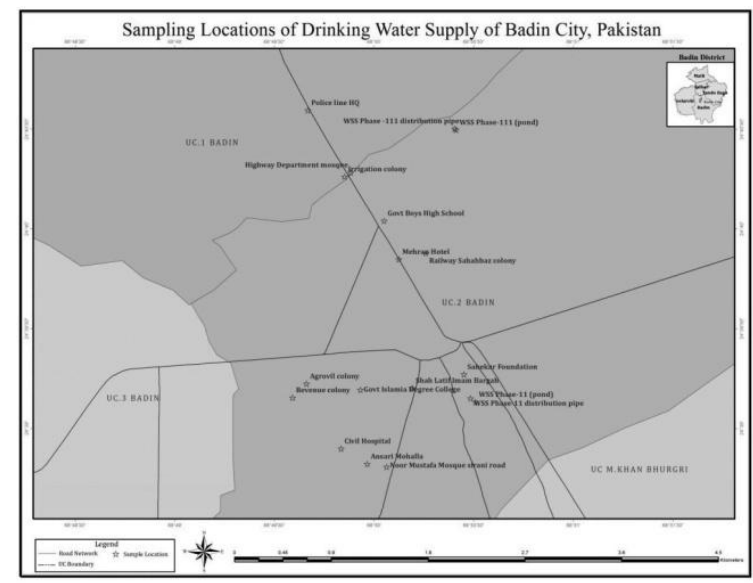

Figure 1: Location of Sampling Sites 
There are two main water supply schemes in the Badin city i.e. Old/Phase II water supply scheme in the city centre and new Phase III water supply scheme at Tando Bago by pass road which supply water to the citizens through distribution network. Eighteen different sites in Badin city were selected, mentioned in Table 1, for sampling purpose. These sites represent main sources/water supply schemes, distribution networks and consumers. All samples were collected following recommended sampling procedures, required for analytical parameters' analysis.

\section{Materials and Methods}

\section{Sampling Techniques, Physico-Chemical and Microbiological Analysis}

All samples were taken under aseptic conditions in sterilized sampling bags (WHIRL-PAK $118 \mathrm{ml}$ ) for microbiological analysis and polystyrene bottles of 0.5 litres for physico-chemical analysis. In order to neutralize residual chlorine 10 percent solution sodium thiosulfate added in sampling bags. After 5 minutes flushing out of standing water from taps, samples were taken and labeled. All samples were kept in ice box at $<4^{\circ} \mathrm{C}$ for a time of 6 hours maximum during field sampling carried out (Godfrey et al. 2006).

\section{Microbiological Parameters}

A portable water testing kit Potalab (WAG-WE 10010; Water Testing-Advanced Long-Term Monitoring Kit, Wagtech International, UK) was used to analyze two microbiological parameters; total coliforms and facecal coliforms. Membrane filtration used to separate and record both microbiological parameters (WagTech, 2010).

Water sample of $50 \mathrm{ml}$ passed through a filter membrane of milipore $45 \mu \mathrm{m}$, and 27 $\mathrm{mm}$ diameter. Medium of Membrane Lauryl Sulphate Broth (MLSB) was prepared using $50 \mathrm{ml}$ de-ionised water in a membrane sulphate media measuring device "MMD” (WagTech, 2010).

Each filter pad was soaked with $2 \mathrm{ml}$ of the MLSB solution. After that, filtered membrane was placed on a pad in petri dish and incubated at an ambient temperature of $28^{\circ} \mathrm{C}$ for 4 hours to allow bacterial resuscitation, before placing to incubators at $44^{\circ} \mathrm{C}$ and $37{ }^{\circ} \mathrm{C}$ for 14 hours for faecal and total coliform bacterial growth respectively. After incubation period, all colonies with yellow color were calculated, multiplied by 2 and recorded by a hand lens as Colony Forming Units (CFU)/100 ml (UNEP/WHO, 1996; Godfrey et al., 2005).

\section{Physico-Chemical Parameters}

Parameters including Turbidity, $\mathrm{pH}$, conductivity and total dissolved solids (TDS) were examined using respective portable meters of the mentioned kit given below in Table 2. 


\section{Residual Chlorine}

Residual chlorine levels of samples were measured with an ISM Hanna HI 93734 instrument (Hanna Instruments, Italy). This device functions according to standard methods for the investigation of water and wastewater that is, 4500-Cl (G), DPD Colorimetric (Mumtaz Shah et al., 2012).

Table 2: Scientific instruments used for water quality analysis

\begin{tabular}{|c|c|c|}
\hline S. $n^{0}$ & Parameters Analyzed & Scientific Instruments \\
\hline 1 & $\begin{array}{l}\text { Electrical } \\
(\mu \mathrm{S} / \mathrm{cm})\end{array}$ & $\begin{array}{l}\begin{array}{l}\text { Conductivity } \\
\text { Wagtech. }\end{array} \\
\text { Wigital Meter WAG-WE } 30210 \\
\end{array}$ \\
\hline 2 & $\begin{array}{l}\text { TDS (Total Dissolved } \\
\text { Salts })(\mathrm{ppm})\end{array}$ & TDS Digital Meter WAG-WE 30210 Wagtech. \\
\hline 3 & $\mathrm{pH}$ & pH 11 Digital Meter WAG-WE 30200 Wagtech . \\
\hline 4 & Turbidity (NTU) & $\begin{array}{l}\text { Aqueous Nephlometric principle ISO } 7027 \text { and US } \\
\text { EPA } 180.1 \text { by Wagtech digital meter. }\end{array}$ \\
\hline 5 & $\begin{array}{l}\text { Total and Faecal Coliforms } \\
\text { (per } 100 \mathrm{ml} \text { ) }\end{array}$ & $\begin{array}{l}\text { Potalab (WAG-WE 10010): Water Testing- } \\
\text { Advanced Long-Term Monitoring Kit. }\end{array}$ \\
\hline 6 & Residual Chlorine (mg/l) & $\begin{array}{l}\text { HANNA Instruments High accuracy Digital and } \\
\text { Chlorine HI } 93734 \text { Free chlorine and Total } \\
\text { Chlorine). (HANNA chemical test kit method Italy). }\end{array}$ \\
\hline
\end{tabular}

\section{Data Analysis}

The mean value of Temperature, $\mathrm{pH}$, Turbidity, TDS, EC, Residual Chlorine, Total and Faecal coliforms along with standard deviation, of all 18 locations was calculated. Analysis of variance (ANOVA) was carried out to test the difference between the groups of above mentioned water quality parameters. Statistical analysis was carried out with Statistix (version 8.1).

\section{Results and discussion}

\section{Temperature}

Temperature plays vital role for the determination of coliforms bacteria and conductivity measurement. Temperature of all samples were measured on site, minimum value recorded was $30^{\circ} \mathrm{C}$ at location $n^{\circ} 1$, and maximum was $33^{\circ} \mathrm{C}$ at location $n^{\circ} 6$. 
Table 3: Physico-chemical and bacteriological results

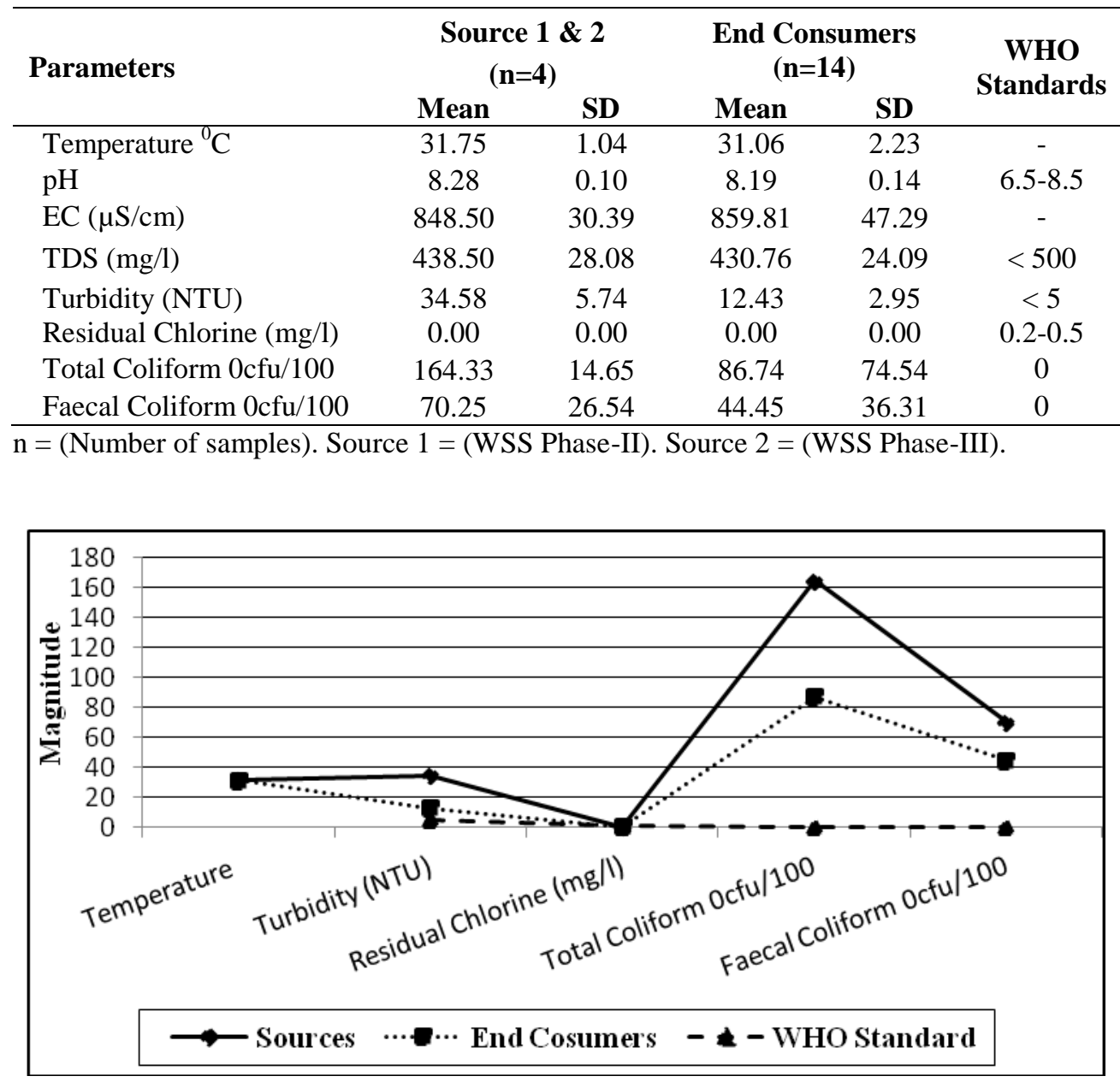

Figure 2: Mean results of critical parameters at source and end consumer level

Table 4: ANOVA results of water quality parameters between the groups

\begin{tabular}{|cccc|}
\hline Variable & DF & F & P* $^{*}$ \\
\hline Coliform Total & $(17,36)$ & 819,76 & 0.0000 \\
\hline Faecal Coliform & $(17,36)$ & 632,94 & 0.0000 \\
\hline pH & $(17,36)$ & 1.04 & 0.4441 \\
\hline Temperature & $(17,36)$ & 0.62 & 0.8547 \\
\hline TDS & $(17,36)$ & 1551.87 & 0.0000 \\
\hline Turbidity & $(17,36)$ & 236.68 & 0.0000 \\
\hline EC & $(17,36)$ & 5296.96 & 0.0000 \\
\hline
\end{tabular}

$* \mathrm{P}<0.05$ : Significance 


\section{Electrical Conductivity (EC), Total Dissolved Solids (TDS) and pH}

The determination of electrical conductivity provides a quick and easy mean of assessing the concentration of electrolytes in water. Greater the dissolved solids stronger would be the conductivity (Kelin et al., 2005). EC varied from 804 to 944 $\mu \mathrm{S} / \mathrm{cm}$ site $\mathrm{n}^{\circ} 5$ and 15 respectively. As results manifest in table 1 , there was direct relationship between TDS and EC. The minimum value of TDS was $403 \mathrm{mg} / \mathrm{l}$ (EC $804 \mu \mathrm{S} / \mathrm{cm}$ ) at location $\mathrm{n}^{\circ} 5$ (Government Islamia Degree College), whereas maximum value was $473 \mathrm{mg} / \mathrm{l}($ EC $944 \mu \mathrm{S} / \mathrm{cm})$ at location $\mathrm{n}^{\circ} 15$ (Mehran Hotel) respectively.

All these sample were found within guidelines of WHO which is $<500 \mathrm{mg} / \mathrm{l}$. These results are in concurrence with the earlier studies of National Water Quality Monitoring Program, PCRWR (2001). pH is an important and critical parameter for proper disinfection and control of bacterial growth which was observed on site. Minimum $\mathrm{pH}$ value was 8.0 at location $\mathrm{n}^{\circ} 5$ (Government Islamia Degree College) and maximum 8.5 was found at location $\mathrm{n}^{\circ} 12$ (Police Line Head Quarter). $\mathrm{pH}$ values of all samples were within the WHO permissible limits of 6.5-8.5. The data of this parameter was in agreement with the previous research studies carried out by National Water Quality Monitoring Program, PCRWR (2001) in which the $\mathrm{pH}$ values were in range 7.0-8.3.

\section{Turbidity}

Turbidity is an important parameter for characterizing the water quality and generally is an expression of optical property that causes light to be scattered and absorbed rather than transmitted light. The minimum and maximum turbidity values ranged between 9-42 NTU at site $n^{\circ} 8$ (Revenue Colony) and II (WSS Phase-III distribution pipe) respectively.

Table 1 represents all values are beyond the limit as suggested by WHO threshold i.e. <5 NTU. Though, turbidity is not an effective indicator for detection of microbial quantity, but it is a good analytical parameter to determine quality of water. While studying of efficiency of chlorination in destroying coliform bacteria in surface water supplies without filtration (LeChevallier et al., 1981) concluded a negative correlation with turbidity. Using a fixed chlorine dose, the derived model projected rise in turbidity from 1.0 to $10.0 \mathrm{NTU}$ resulting in eight-fold decrease in the disinfection efficiency.

\section{Residual Chlorine}

Analyses of residual chlorine values were found $0 \mathrm{mg} / \mathrm{l}$ in all the eighteen samples Table 1, which are contrary to recommended level $0.2-0.5 \mathrm{mg} / \mathrm{l}$ of WHO guidelines. The similar findings have also been reported by (Shar et al., 2008a), they found 0 $\mathrm{mg} / \mathrm{l}$ residual chlorine in all 90 water samples analyzed form main reservoir, distribution-line and consumer taps in Khairpur city of Sindh. The unavailability of 
residual chlorine in the water system implies lack of proper water treatment at all levels of water systems, which could be health hazard to the population of the city.

\section{Bacteriological analysis}

Bacteriological studies were conducted for the determination of total and faecal coliforms bacteria present in the drinking water. Coliforms bacteria are present in the soil, water, human colon or animal waste. The detection of coliform contamination in drinking water indicates flaws in treatment systems as untreated sewage water being directly flowed into the fresh water canals. Secondly, drinking water during distribution process gets contamination from sewage system, as presence of Faecal Coliform and E.Coli indicate water may be contaminated with human or animal wastes and intake of contaminated water pose serious health risks of waterborne diseases among the community.

These microorganisms are the causative agents of waterborne diseases including diarrhoea, typhoid, Hepatitis A/E and other symptoms. Total and faecal coliforms found in our findings are in same line with the studies reported throughout Pakistan regarding drinking water of Hyderabad (Pak-EPA Report 2004), Rawalpindi (Farooq et al., 2008), Khairpur city (Shar et al., 2008) and Karachi city (Malick et al., 1998).

Guidelines for Drinking Water WHO (2011) and Quality Drinking Water Standards for Pakistan QDWSP (2007) recommend that E. coli or thermo tolerant coliform bacteria must not be detectable in all water directly intended for drinking. However, present study shows situation is totally in disagreement with the recommended values set by WHO and QDWSP. Waterborne alerts and outbreaks are high because above 40percent water supply is unfiltered and 60 percent of effluents disposed of without treatment (Water Aid Pakistan 2010-15).

Therefore, it is the responsibility of federal and provincial government authorities including ministry of environment, PHED, and Local Government to implement Pakistan Drinking Water Quality Standards (2009) to improve water quality before supplying to the communities. Additional water supply schemes will be established and current will be reformed and improved in urban and rural areas to ensure sustainable access to safe drinking water to entire population of Pakistan (Government of Pakistan, 2009).

\section{Statistical Analysis}

Details of water quality results are summarized in Table 3. Overall higher mean values of Temperature, $\mathrm{pH}$, Turbidity, Total and Faecal coliforms occurred at source level and reverse was true in case of EC at end consumer level. While, residual chlorine was neither found at source nor end consumer level. Total and Faecal coliforms were higher at source level than end consumer level (Table 3), there could be different possible reasons, this is likely due to poor sanitary condition 
of water storage ponds and absence of proper water treatment at water supply schemes phase II and III.

However, drinking water is unhealthy among all end consumer levels with different number of coliform bacteria, probably because of insanitary distribution system; unhygienic conditions and consumers' behaviours related to drinking water at household levels, this is also evident from higher standard deviation of total coliform (74.54) among end consumers at different fourteen locations in comparison to lower standard deviation (14.65) at source level.

Figure 2 shows critical drinking water quality parameters, with source highly polluted and out of compliance with WHO standards. Analysis of variance for drinking water quality parameters showed highly significant differences for Turbidity, TDS, EC, Residual Chlorine, Total and Faecal coliforms $(\mathrm{p}<0.05)$, however difference was not significant in $\mathrm{pH}$ and Temperature ( $\mathrm{p}>0.05)$ (Table 4).

\section{Recommendations}

Regulatory framework like Pakistan Environmental Protection Act 1997 and National Drinking Water Policy 2009 do exist in Pakistan, but there is no clear strategy devised so far to implement these regulations (WB-CWRAS 2005). The daunting situation of drinking water quality needs priority at different levels of administration to develop a strong and sustainable water surveillance system in district Badin to protect the health of the communities and decrease their health expenses. To achieve this, following steps are recommended for ensuring provision of safe drinking water;

- Root cause of water contamination is poor sanitation, foremost initiative is to consider improved sanitation as priority issue at national, provincial, district, taluka, town, Union Council (UC) and village level to curb open defecation and improve sewerage systems.

- Role of Provincial Environmental Protection Agency, Public Health Engineering Department and Local Government is critical; it needs high attention and enforcement of laws to minimize water pollution particularly surface water canals which are used for drinking purpose.

- Rehabilitation of ponds at water supply schemes and replacement of outdated distribution lines is very necessary. Moreover, storage ponds need stone-pitching from walls and regular cleanliness from time to time, distribution lines were laid decades ago which are now wretched and facilitating adulteration of contamination from sewers and illegal selfplumbing connections that must be halted. 
- At district level, strong coordination among PHED, Taluka Municipal Administration, health department, and district government is desirable to share information about water quality, and waterborne diseases. In the wake of the results, locally feasible strategies should be applied for the improvement.

- Capacity building of staff serving water supply schemes is must and they should be equipped with better monitoring and proper treatment supplies.

- Regular monitoring of water quality at source, distribution network and end user level should be conducted especially microbiological contamination, as it could cause waterborne alerts/outbreaks among the community within short period of time. In the light of water surveillance results, any fault detected should be corrected accordingly.

- City, town and rural areas' water supply schemes are working under TMAs and PHED, therefore district government must be proactive to oversight well-functioning performance of these authorities.

- NGOs and media can raise awareness about use of safe drinking water, and pinpoint water pollution locations to draw attention of concerned authorities in order to take timely action against violators and undertake remedial measures for improvement.

- Water protection/surveillance committee can be established under district government with representation from local NGOs, print and electronic media, TMAs, PHED, PCRWR, and Member of Provincial Assembly (MPA) of the area to strengthen and ensure quality drinking water system.

\section{Conclusions}

The results presented in this paper show that all water samples found polluted with total and faecal coliform bacteria mostly with large number of colonies, which is a major health risk of waterborne diseases for the citizens and particularly children under five. Besides, no residual chlorine is detected in any of water samples analyzed that indicated poor treatment mechanism at the source level and, of course quality is unsafe too at the end consumer level as water passes through deplorable distribution network and unsanitary conditions.

\section{Acknowledgements}

This research has been made possible with Potalab water testing laboratory during affiliation of corresponding author with World Health Organization, Pakistan. We are grateful for the helpful comments provided by anonymous reviewers. 


\section{References}

Anwar, M. S., Chaudhry, N. A., Tayyab M. (1999). Bacteriological quality of drinking water in Punjab: evaluation of H2S strip test. Journal Pakistan Medical Association, 49(10), 237-41.

Anwar, M. S., Chaudhry, N. A., Tayyib M. (2004). Qualitative assessment of bacteriological quality and chlorination status of drinking water in Lahore. $J$ Coll Physicians Surg Pak, 14: 157-60.

Farooq, S., Hashmi, I., Qazi, I.A., Qaiser, S., Rasheed, S., 2008. Monitoring of coliforms and chlorine residual in water distribution network of Rawalpindi, Pakistan. Environ Monit Assess, 140: 339-47.

Godfrey, S., Timo, F. and Smith, M. (2005). Relationship between rainfall and microbiological contamination of shallow groundwater in Northern Mozambique. South African Water Association, 31(4): 609-614.

Godfrey, S., Timo, F. and Smith, M. (2006). Microbiological risk assessment and management of shallow groundwater sources in Lichinga, Mozambique. Water and Environment Journal, 195: 194-202.

Government of Pakistan (2009). National Drinking Water Policy, Ministry of Environment.

Government of Pakistan (2008). Pakistan Demographic and Health Survey 2006-2007.

Government of Pakistan (2007). Drinking Water Quality: standards for Pakistan, Ministry of Health, Health Services Academy in collaboration with WHO.

Government of Pakistan. Survey of Pakistan., Available: http://www.surveyofpakistan.gov.- pk / [Accessed February 2, 2013].

Government of Sindh. Map of Sindh. Available: http://www.sindh.gov.pk/ [Access- ed February 2, 2013].

Hussain, M., Rasool S. A., Khan, M. T., Wajid, A. (2007). Enterococci vs coliforms as a possible faecal contamination indicator: baseline data for Karachi. Pak J Pharm Sci $20,107-11$.

Kelin, H., Yuang, H. F., Hong, L., and Robert, W. E. (2005). Spatial variability of shallow ground water level, electrical conductivity and nitrate concentration and risk assessment of nitrate contamination in North China plain. Environment International, 31: 896-903.

Kosek, M., Bern, C., Guerrant, R. (2003). The global burden of diarrhoeal disease, as estimated from studies published between 1992 and 2000, Bull. W. H. O., 81(3): 197-204. 
LeChevallier, M. W., Evans, T. M. and Seidler, R. J. (1981). Effect of turbidity on chlorination efficiency and bacterial persistence in drinking water. Applied and Environmental Microbiology, 42: 159.

Malick, F. K., Akhtar, W. and Seema, J. (1998). Drinking water quality in the city of Karachi. In 24th WEDC conference, sanitation and water for all. Islamabad: Pakistan.

Memon, M., Soomro, M. S., Akhtar, M. S., Memon, K. S. (2010). Drinking Water Quality Assessment in Southern Sindh (Pakistan). Environ Monit Assess, 177: 39-50.

Mumtaz, S., H. N. Hashmi, Mumtaz, A. K. and Abdul Razaq, G. (2012). Residual chlorine modeling in water distribution system: A case study of defence housing scheme (DHS), Lahore. International Journal of the Physical Sciences, 7(33): 5266-5272.

Mumtaz, M. W., Adnan, A., Mukhtar, H., Nawaz, K., Raza, A. and Ahmad, Z. (2010). Estimation of bacteriological levels in surface water samples to evaluate their contamination profile. Environ Monit Assess 2010 Published online.

Pak-EPA Report (2004). Investigation of contamination of drinking water in Hyderabad City. Islamabad: Pakistan Environmental Protection Agency. Pak-EPA, Central Laboratory for Environmental Analysis. Ministry of Environment.

PCRWR (2001). National water quality monitoring program. In World water day workshop, Islamabad (March).

PCRWR (2004).Water Quality Profile of Pakistan (22 Cities) Report (Phase-III) 20032004. Pakistan Council for Research in Water Resources, Islamabad available from: http://www.pcrwr.gov.pk/Researchpercent20Report/National percent20Waterpercent20Qualitypercent20Monitoringpercent20Program/waterperce nt20qualitypercent20statuspercent20inpercent20pakistanpercent20Phaseiiipercent202003-2004.pdf [Accessed 14 July 2012].

PCRWR (2007). National Water Quality Monitoring Programme Annual Report 20052006, Pakistan Council for Research in Water Resources, Islamabad. Available from: http://www.pcrwr.gov.k/Annualpercent20Reports/Newpercentage20Annualpercent20 Repotpercent202005-06_2.pdf [Accessed 14 July 2012].

Rosemann, N. (2005). Drinking water crisis in Pakistan and the issue of bottled water. The case of Nestlé's 'Pure Life'. Pakistan: Swiss Coalition of Development Organisations and Actionaid. Available from: http://www.alliancesud.ch/en/policy/water/downloads/nestle-pakistan.pdf [Accessed 14 July 2012].

Shar, A. H., Kazi, Y., Zardari, M., Soomro, I. H. (2008a). Enumeration of total and faecal coliform bacteria in drinking water of Khairpur Sindh. Pak J Med Res., 47: 18-21.

Shar, A. H., Kazi, Y. F., Soomro, I. H. (2008b). Impact of seasonal variation on bacteriological quality of drinking water. Bangladesh J Microbiol., 25: 69-72.

Sarwar, G., Khan, J., Iqbal, R., Afridi, A. K., Khan, A. and Sarwar, R. (2004). Bacteriological analysis of drinking water from urban and peri-urban areas of 
Peshawar. Journal of Postgraduate Medical Institute, Khyber Medical College, Peshawar, 18: 64-9.

Prüss, A., Kay, D., Fewtrell, L., Bartram, J. (2002). Estimating the burden of disease from water, sanitation and hygiene at a global level. Environ. Health Perspect., 110(5): $537-542$.

UNEP/WHO (1996). Chapter 10 - Microbiological Analyses. In: Jamie Bartram and Richard Ballance, ed, Water Quality Monitoring - A Practical Guide to the Design and Implementation of Freshwater Quality Studies and Monitoring Programmes. UK: E\&FN Spon 2-6 Boundary Row, London SE1 8HN.

UNICEF/WHO (2009). Diarrhoea: Why Children are Still Dying and What can be Done. WHO, Geneva, 2009.

WagTech (2010). Advanced Long-Term Monitoring Kit - Potalab (WAG-WE 10010), Operational Manual.

WaterAid Pakistan (2010). Country Strategy 2010-15, 14.

WHO and UNICEF (2008). Joint Monitoring Programme for Water Supply and Sanitation (JMP) World Health Organization (WHO) and United Nations Children's Fund (UNICEF). Progress on Drinking Water and Sanitation: Special Focus on Sanitation, New York.

WHO (2011). Guidelines for Drinking-water Quality (4th edition), Malta: Gutenberg WBCWRAS, 2005.Pakistan Country Water Resources Assistance Strategy, water economy: Running dry. Report No. 34081-PK. Washington DC: The World Bank, November 14, 2005.

WWF (2007). Pakistan's waters at risk Water and health related issues in Pakistan and key recommendations. pp. 1-33

Zahoorullah., A. T. and Zai, S. (2003). Quality of drinking water in rural Peshawar. Pak J Med Res., 42: 85-89. 